\title{
Building Marketing Capabilities as a Way to Form a Better Global Marketing Strategy
}

\author{
Alharbi Adel Saleh $\mathrm{M}^{1}$, Wang Aimin ${ }^{2}$ \\ ${ }^{1,2}$ Wuhan University of Technology, Wuhan, China
}

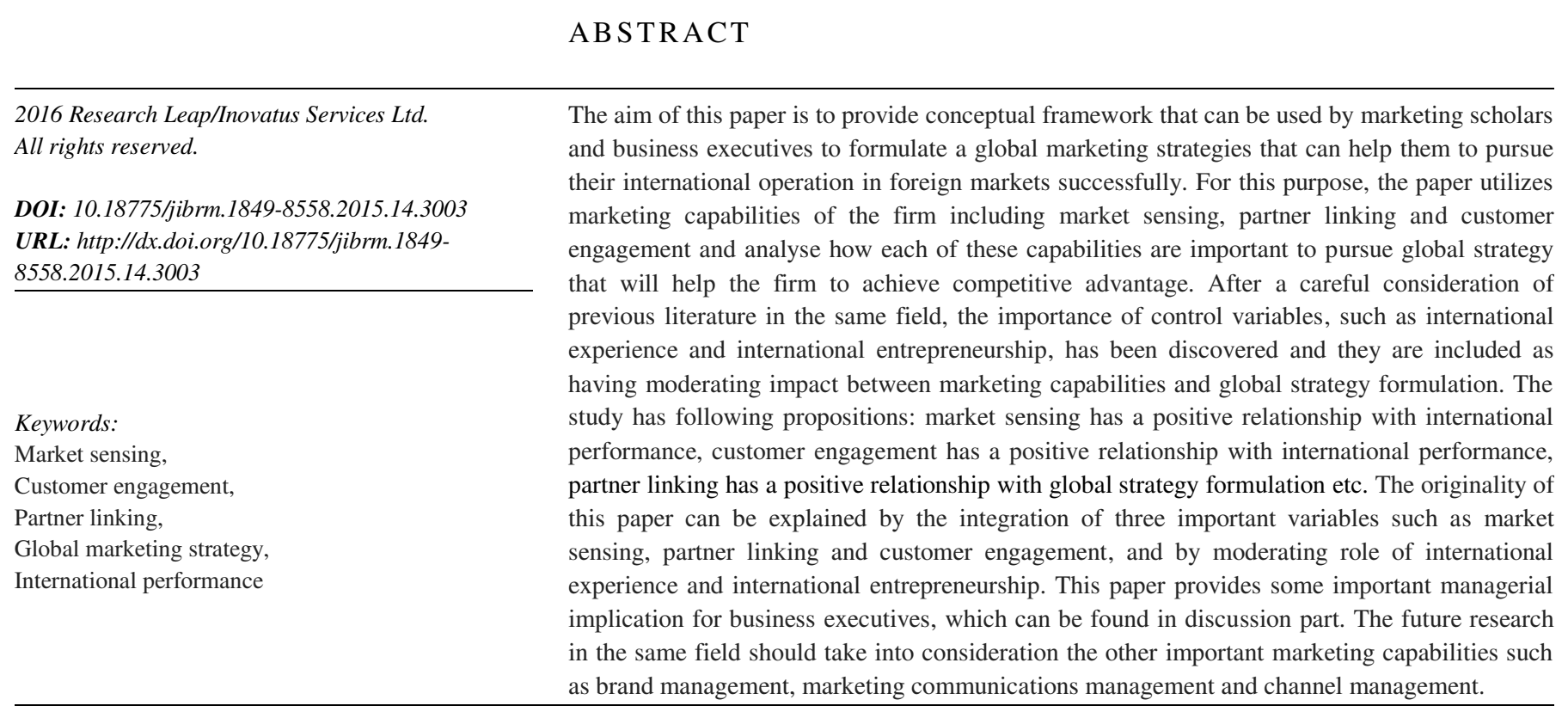

\section{Introduction}

Understanding marketing environment and being equipped with the latest technological advances as well as having the latest information about the market trends in international market are considered as an important prerequisite for formulating good marketing strategy. Market orientation of the firm is defined by organizational strategy. That is to say, using organizational strategy, market orientation of the firm is determined in relation to customers, competitors and market forces. There are numerous numbers of studies that have been conducted to identify the best means of formulating marketing strategy. When the issue of marketing strategy is discussed, most marketing scholars highlight the significance of marketing capability, which is considered as a backbone of formulating a strong marketing strategy. Previous literature in the marketing strategy has reported a positive link between strong marketing capabilities and firm success (Kanibir et al., 2014, Ripolles, 2011). Moreover, most of the scholars highlighted the enormous role of marketing in achieving firm success and strong positioning in the market. Marketing capabilities are also believed to contribute to the international expansion of the firms. The role of marketing capabilities has also been studied in relation to company profit. The study conducted by Morgan (2009) analysed the influence of marketing sensing, brand management and customer engagement on company growth. Morgan (2009) found a significant positive relationship between marketing capabilities and company growth. Marketing literature also proposed different elements of marketing capabilities such as market sensing, customer engagement and partnership capabilities. All these elements are reported as the fundamental prerequisites of marketing capability, which will contribute to the establishment of competitive advantage. Product innovations are directly related to success of the companies in international market. In this regard, most of the previous literature stated that companies with strong marketing capabilities are more likely to make innovative products.

\section{Literature review and model development}

The importance of marketing capabilities in ensuring the success of firms in international market has been widely discussed among marketing scholars for the last three decades (Park et al., 2010; 
Dyer \&Singh, 1998; Mu \& Di Benedetto, 2012; Teece, 2007). Marketing capabilities are regarded as the ability of the firm through, which company can react to changing market environment, exploit new opportunities, engage with customers by providing their products and services according to the needs of customers and building strong relationship with company partners in exchange of resources and capabilities. In other words, market sensing, customer engagement and partner linking are believed as the main cornerstones of marketing capabilities which contribute to the formulation of global strategy. Pursuing right global market strategy helps firms to achieve competitive advantage based on which companies can operate successfully in international market.

H1: Market sensing has a positive relationship with international performance

Marketing sensing capability provides an opportunity for the companies to react on time and efficient manner towards changing market trends including consumer wants and needs. (Day, 1994; Du \& Kamakura, 2012). Therefore, it can be stated that market sensing involves the collection of necessary information that might be later used to formulate necessary strategies in order to respond well to evolving and rapidly changing market conditions. Market sensing capabilities also help firms to identify market opportunities earlier than competitors (Weick, et al. 2005).Therefore, it can be mentioned that good market sensing information not only requires having good knowledge or understanding of changing marketing trends but also requires efficient organizational information processing capabilities such as filtering, explanation of new knowledge and sorting necessary information. Market sensing is crucial in order to transform market circumstances into situations, which can lay the ground for action (Mu \& Di Benedetto, 2012; Teece, 2007). In other words, it implies that a firm can benefit from having structured risk analysis process and mitigate the potential of losses and achieve superb results from having a strong market sensing capabilities. Therefore, it is crucial to have a better understanding of changing market opportunities and trends before they are fully evolved. This kind of knowledge is considered to be crucial in operations of the firm, especially in international markets, where the market and industry trends are more likely to change and market opportunities may evolve in constant and ongoing basis.

H2: Customer engagement has a positive relationship with international performance

Customer engagement involves formulating close relationship with the customers in order to better satisfy their wants and needs (Mu \& Di Benedetto, 2012). This concept may also be useful in terms of increasing the number of existing customers through close engagement with them. Previous studies found a positive link between customer engagement and firm performance and superior financial performance (Ullah et al, 2016). Adaptation to the changing marketing environment requires having strong customer engagement capabilities through which changing market opportunities might be identified (Park, et al, 2010).
Consumer centric approach is regarded as the focal point of customer engagement. Better customer expectations are also developed through customer engagement capabilities (Park et al., 2010). Having high levels of customer engagement is more likely to lead to having a better customer experience, satisfaction and consequently loyalty towards company offering. Loyal customers are essential for the success of the company in international markets (Yim et al, 2008). Word of mouth marketing is strongly promoted through loyal customers who will contribute to the increasing number of new customers. International performance of the firm can be characterized by the increasing market share, financial performance of the firm, which is directly related to customer satisfaction and loyalty, which is an integral focus of customer integration.

H3: Partner linking has a positive relationship with global strategy formulation

Partner linking is described as the capability of the firm through which it can set contact with its partners and make efficient use of current resources $(\mathrm{Mu}, 2014)$. The importance of partner linking becomes more relevant in the case of open market operations where it is crucial asset to exchange needed knowledge and skills in order to provide on time information for partners (Dyer \&Singh, 1998). Partner linking can help the firms to achieve value creation through having better relations among parties and having access to deep set of information resources, which can be shared among partners (Day, 1994). In order to create product innovation and achieve high level of customer satisfaction it is important to have efficient integration of resources and skills among business partners ( $\mathrm{Mu}, 2013)$. The more diverse the availability of resources and capabilities among partners, the more efficient they will be in achieving high levels of customer value and they will increase their efficiency in terms of creating new product. Therefore, it is important for the firms to stay aware of market changes in order to have ongoing relationship with the partners (Saif, 2015). To sum up, it can be mentioned that partner linking is beneficial from two perspectives (Day, 1994). First of all, it helps companies to exploit new opportunities and knowledge which can be used to adapt to environmental changes. Secondly, partner linking is useful in terms of refining new knowledge between partners in order to maximize the efficiency of the resources which companies can possess.

H4: Market sensing has an impact on global marketing strategy formation

The success of the firms are not only determined by implementing marketing mix, but also by executing successful marketing strategy, which will help them to be successful in international markets (Day \& Wensley, 1988). Appropriate and effective marketing strategy is found to be crucial in terms of proposing right deployment of resources and their appropriate allocation, which is collected through market sensing. Careful consideration of market sensing definition reveals that market sensing involves collection and dissemination of information that is necessary regarding ongoing market trends and changing 
market conditions. Being provided with this type of information on time, firms will be equipped with necessary knowledge that will help them to formulate right strategy to compete in global market (Mariadoss, et al, 2015). Market sensing provides companies with relevant and on time information about the changing market conditions and new business opportunities that will aid them in creating competitive advantage, which is important in formulation of successful global strategy (Day $\&$ Wensley, 1988). Therefore, most of the previous literature analysing the impact of factors that will contribute to the success of global market strategy formulation found a positive relationship between market sensing and global market strategy. H5: Customer engagement has an impact on global marketing strategy formation

There is a rapidly growing literature on the global marketing strategy formulation that suggests that in order to be successful in the global market, businesses should operate taking into consideration the needs and wants of customers (Miller et al, 1998). This involves selecting right target market of the business through dividing the entire market into segments. Dividing market into different groups allows the firms to better target their potential and existing customers with product and service offers. This will help the company to develop better relationship with the customers of the company, without which businesses are not able to exist and succeed (Homburg at al, 2000). Customer engagement refers to building a long lasting relationships with customers and determining right marketing objectives, and a tailoring company's efforts towards these objectives help companies to achieve their long-term goals (Reinartz, 2004). Most marketers are pursuing consumer centric approach to product centric approach as the former one is crucial in ensuring the success of global marketing strategy

H6: Partner linkages have an impact on global marketing strategy formation

Partner linkages have shown an increasing importance among marketing scholars for the last years due to their significance in formulation of successful global marketing strategy (Miller et al, 1998). The ability of the firm to collaborate and exchange the necessary information among partners helps the companies to exploit innovative products and create superior customer value, which is the crucial aspect of any global marketing strategy (Lockrey, 2015). Partner linking is found to make efficient use of firm resources and capabilities, which can be beneficial in terms of creating innovative products (Homburg et al, 2000). Creation of innovative products is the focal point of acquiring the attention of customers who always look for new ways to satisfy their needs using most efficient and cost effective ways. Therefore, close collaboration and ongoing contact with firm partners helps companies to recombine and re-bundle the resources and capabilities of the firm and results in successful marketing strategy formulation (Reinartz, et al, 2004).

H7: International experience has a moderating effect between marketing capabilities and global marketing strategy formation
Marketing capability of the firm includes market sensing, customer engagement and partner linking which are the core bases of the firm in achieving long-term success (Day, 1994). These three important functions of marketing capability are believed to be interdependent with each and having enough knowledge. Experience on the implication of these three variables is crucial in formulating global marketing strategy. In this regard, most previous studies found a moderating role of international experience between marketing capabilities and global strategy formulation $(\mathrm{Mu}, 2015)$. Application of strong market sensing capability requires on time approach to changing market trends and exploitation of new opportunities from firms, which is impossible without the moderating role of international experience. International experience is also crucial in achieving the means of adaptation, coordination of marketing activities and integration of competitive action which are the bases of global marketing strategy of the firm (Kaplan \&Norton, 1994). The importance of international experience is mainly highlighted in its moderating role between market sensing and global strategy formulation (Sok, et al, 2013).

H8: International entrepreneurship has a moderating effect between marketing capabilities and global marketing strategy formation

International entrepreneurship is also found to play moderating role between marketing capabilities and global marketing strategy formulation (Morgan, 2009). Precisely, the importance of international entrepreneurs is observed in terms of their role in customer engagement and global strategy formulation. Similar to the capability of the market sensing, customer engagement helps companies to reflect on ongoing changes in customer behaviour and market trends, and it allows the firms to maintain strong customer expectations (Day \& Moorman, 2010). Therefore, entrepreneurship is believed to be an important mean of customer engagement and global marketing strategy formulation.

H9: Global marketing strategy plays a significant role in performance of firms on the international market

Global marketing strategy involves standardization, coordination of marketing activities and integration of competitive actions in itself. The notion of Porters generic strategies provides the concept of three important strategies that firms use including cost leadership, differentiation and focus strategies, which are used by many world famous firms in order to ensure the success of their international performance. Pursuing these global marketing strategies requires from firms strong marketing capabilities (Teece, et al., 2007). These capabilities include market sensing, partner linking and customer engagement, which are the crucial backbones of each global strategy. When these marketing capabilities are properly used, firms are believed to achieve certain strong position in the international market (Day, 1994). Market sensing, customer engagement and partner linking allow firms to stay alert regarding the changes in market trends including those such as customer preferences, exploitation of new market opportunities and collaboration with partners. Therefore, successful 
participation in foreign market requires from firms to become aware of market trends and customer needs all of which are achieved through effective utilization of global marketing strategy

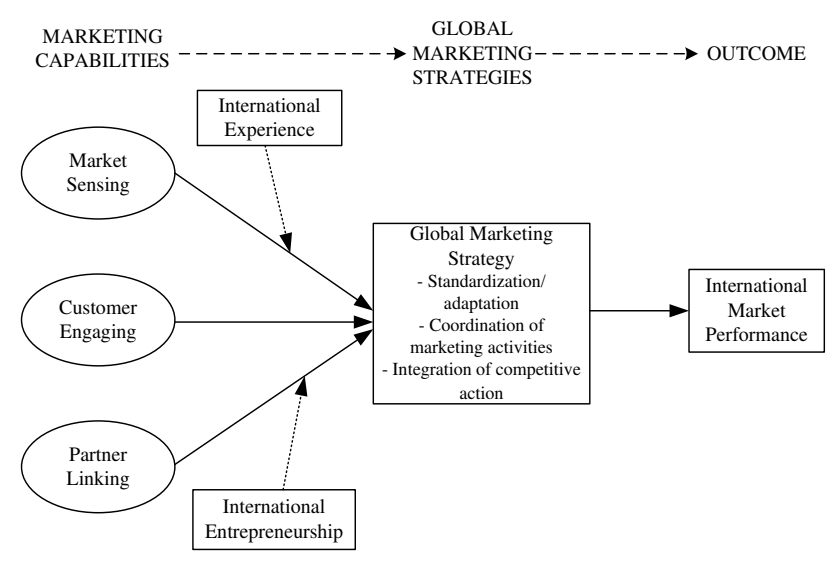

\section{Discussion and implications}

Market sensing, customer engagement and partner linking are proposed to have positive link with formulating global marketing strategy. Market sensing is one of the important marketing capabilities which allow firms to react to external changes in market environment. Likewise, customer engaging and partnership linking allows firm to build a strong relationship with company's prospective and current customers as well as partners. The analysis of previous literature mentioned number of important criteria to maintain the stability of marketing strategy including adaptation, coordination of marketing activities and integration of competitive action. The study has different implications for business practitioners and marketing experts who are always in constant search for new strategies to succeed in the market. International experience and international entrepreneurship are regarded as the moderating variables among marketing capabilities and global marketing strategy. The adequate understanding the importance of marketing capabilities by business practitioners are found to lead for the success in international market performance.

\section{Conclusion}

This paper proposed conceptual framework, which is focused on the usage of marketing capabilities in order to formulate strong global marketing strategy. Most companies are constantly looking for the ways to go global and offer their products and services in international markets. Therefore, strong implementation of right marketing strategies is becoming even more vital in order to ensure the success of companies in international market. Extensive review of the previous literature in the area leads to the development of different characteristics contributing to the success of the marketing strategy revealed the significance of marketing capabilities, which are defined as the ability of the companies to react and cope with changes in external market environment. Marketing capabilities are reported to consist of market sensing, customer engagement and partner linking. These are three important elements which aim to strategy adaptation, coordination of marketing activities and integration of competitive actions. Pursuing right global marketing strategy is expected to contribute for maintaining strong market position in the international business level.

\section{References}

- $\quad$ Lockrey, S (2015), 'A review of life cycle based ecological marketing strategy for new product development in the organizational environment', Journal of Cleaner Production, vol. 95, pp. 1-15, CrossRef

- Morgan, N. A., Vorhies, D. W.,\& Mason, C. H. (2009).Market orientation, marketing capabilities, and firm performance. Strategic Management Journal, 30(8), 909920, CrossRef

- Mariadoss,B. J., Tansuhaj, P. S., \&Mouri, N. (2015). Marketing capabilities and innovation-based strategies for environmental sustainability: An exploratory investigation of B2B firms. Industrial Marketing Management,40(8), 1305-1318, CrossRef

- Sok, P., \&O' Cass, A. (2013).The role of intellectual resources, product innovation capability, reputational resources and marketing capability combinations in SME growth. International Small Business Journal, Porter, M. E. (1985). Competitive strategy: Creating and sustaining superior performance. The free, New YorkDu, R.Y., \& Kamakura, W.A. (2012). Quantitative trend spotting. Journal of Marketing Research, 49(4), 514-536.

- Morgan, N. A., Anderson, E. W., \& Mittal, V. (2005). Understanding firms' customer satisfaction information usage. Journal of Marketing, 69(3), 131-151, CrossRef

- $\quad$ Teece, D. J., Pisano, G., \& Shuen, A. (1997). Dynamic capabilities and strategic management. Strategic management journal, 18(7), 509-533, CrossRef

- Day, G. S. (1994). The capabilities of market-driven organizations. the Journal of Marketing, 37-52, CrossRef

- Weick, K. E., Sutcliffe, K. M., \& Obstfeld, D. (2005).Organizing and the process of sense making. Organization Science, 16(4), 409-421, CrossRef

- Mu, J., \& Di Benedetto, C.A. (2012). Networking capability and new product development. IEEE Transactions on Engineering Management, 59(1), 4-19, CrossRef

- $\quad$ Park,W.C.,MacInnis, D.J., Priester, J., Eisingerich, A.B., \& Iacobucci, D. (2010). Brand attachment and brand attitude strength: conceptual and empirical differentiation of two critical brand equity drivers. Journal of Marketing, 74(6), 1-17, CrossRef

- Yim, B.C.K., Tse, D.K.,\& Chan, K.W. (2008). Strengthening customer loyalty through intimacy and passion: roles of customer-firm affection and customerstaff relations in services. Journal of Marketing Research, 45(6), 741-756, CrossRef

- $\mathrm{Mu}$, J. (2014).Networking capability, network structure and new product development performance. IEEE Transactions on Engineering Management, 61(4), 599-609, CrossRef 
- Dyer, J.H., \& Singh, H. (1998). The relational view: cooperative strategy and inter-organizational competitive advantage. Academy of Management Review, 23, 660-679, CrossRef, CrossRef

- $\quad$ Day, G.S., \&Wensley, R. (1988).Assessing advantage: a framework for diagnosing competitive superiority. Journal of Marketing, 52, 1-20 (April), CrossRef

- $\quad$ Miller, D., Droge, C., \& Toulouse, J.M. (1988).Strategy process and content as mediators between organizational context and structure. Academy of Management Journal,31(3), 544-569, CrossRef

- Homburg, C., Droll, M., \& Totzek, D. (2008). Customer prioritization: does it pay off, and how should it be implemented? Journal of Marketing, 72(5), 110-130, CrossRef

- Reinartz, W., Krafft, M., \&Hoyer, W.D. (2004). The customer relationship management process: its measurement and impact on performance. Journal of Marketing Research, 41,293-305, CrossRef

- Kaplan, R.S., \& Norton, D.P. (1992). The balanced scorecard: measures that drive performance. Harvard Business Review, 70(1), 71-79

- Ullah, A., Ahmed, M., Zhukov, D., (2016). Achieving service innovation through market orientation. The role of relationship marketing and knowledge management. International Journal of Management Science and Business Administration, 2(2), 19-28, CrossRef

- Saif, A., (2015). How does marketing strategy influence firm performance? Implementation of marketing strategy firm success. International Journal of Innovation and Economic Development, 3(1), 7-15, CrossRef

- Zentes, J. (1996), Grundbegriffe des Marketing, 4th ed., Schäffer-Poeschel, Stuttgart. Pakistan. International Journal of Bank Marketing, 33(4). 